\title{
Post-challenge hematological evaluation with virulent strain of Eimeria tenella in broilers immunized with attenuated strain or sporozoite proteins from homologous strain
}

Avaliação hematológica pós-desafio com cepa virulenta de Eimeria tenella em frangos de corte imunizados com cepa atenuada ou proteínas de esporozoítos de cepa homóloga.

Alexey Leon Gomel Bogado ${ }^{1,2 *}$; João Luis Garcia ${ }^{1}$; Patrícia Fernandes Nunes da Silva ${ }^{3}$; Mara Regina Stipp Balarin ${ }^{1}$; José da Silva Guimarães Junior ${ }^{1}$

\author{
${ }^{1}$ Departamento de Medicina Veterinária Preventiva, Centro de Ciências Agrárias, Universidade Estadual de Londrina - UEL \\ ${ }^{2}$ Programa de Pós-Graduaçáo em Ciência Animal, Universidade Estadual de Londrina - UEL e Bolsista CNPq \\ ${ }^{3}$ Programa de Pós-Graduação em Ciência Animal, Universidade Estadual de Londrina - UEL e Bolsista CNPq
}

Received July 8, 2009

Accepted September 10, 2009

\begin{abstract}
Hematological parameters were evaluated in broilers immunized and challenged with Eimeria tenella. Broiler chickens of Hubbard strain, females, coccidian-free, were kept in wire cages and inoculated on the third day. The experiment was designed to include five sorts of treatment with three replicates each. T1 was the negative control group, T2 received 500 attenuated sporulated oocysts by gavage, T3 was the positive control, T4 received $50 \mu \mathrm{g}$ of sporozoite protein + Quil A vaccine, and T5 received Quil A without sporozoite protein + PBS, the last two through nasal route on days 0,7 , and 21 . On the $31^{\text {st }}$ day, all treatments were challenged with homologous virulent strain of E. tenella in the dose of $8.0 \times 10^{4}$ oocysts, with the exception of T1. One week later, blood sampling, lesion scores, and cecal oocyst count were carried out. The parasitological parameters showed statistical significance $(p<0.05)$ and there was no damage to the hematological parameters of birds $(\mathrm{p}>0.05)$ by ANOVA test. The correlations suggest that the blood parameters were impaired by effects of the parasite on tissue, showing levels of hemorrhage and/or hydration.
\end{abstract}

Keywords: Eimeria tenella, hematology, attenuated strain, sporozoite protein.

\section{Resumo}

Foram avaliados os parâmetros hematológicos em frangos de corte imunizados e desafiados com Eimeria tenella. Pintos de corte fêmeas da linhagem Hubbard, livres de coccídios, foram mantidos em baterias metálicas e inoculados no terceiro dia. $\mathrm{O}$ experimento foi delineado por cinco tratamentos com três repetiçóes cada, sendo: T1 controle negativo, T2 recebeu 500 oocistos esporulados atenuados via oral, T3 controle positivo, T4 recebeu vacina contendo $50 \mu \mathrm{g}$ de proteínas de esporozoítos + Quil A e T5 recebeu Quil A + PBS, sendo os dois últimos por via nasal nos dias 0, 7 e 21. No dia 31, todos os tratamentos foram desafiados com cepa virulenta homóloga de E. tenella na dose de 8,0 $\times 10^{4}$ oocistos, exceto T1. Uma semana depois, foi realizada amostragem de sangue, escore de lesão e contagem de oocistos cecais. Os parâmetros parasitológicos apresentaram significância estatística $(\mathrm{p}<0,05)$, sem que causassem prejuízos aos parâmetros hematológicos das aves ( $p>0,05)$, pelo teste ANOVA. As correlações sugerem que os parâmetros sanguíneos foram afetados pelos efeitos do parasita no tecido, apresentando níveis de hemorragia e/ou hidratação.

Palavras-chave: Eimeria tenella, hematologia, cepa atenuada, proteínas de esporozoítos.

\footnotetext{
*Corresponding author: Alexey Leon Gomel Bogado Departamento de Medicina Veterinária Preventiva,

Centro de Ciências Agrárias, Universidade Estadual de Londrina - UEL,

Campus Universitário, Rod. Celso Garcia Cid, PR 445, km 380,

CP 6001, CEP 86051-990 Londrina - PR, Brasil;

e-mail: alexey@yahoo.com.br

Supported by: CNPq.
} 


\section{Introduction}

The poultry coccidiosis is one of the most important parasitic diseases of chickens and the main species commonly found in field are Eimeria acervulina, E. maxima, and E. tenella, each one infecting a specific region of the intestine (LILLEHOJ et al., 2004).

Eimeria tenella, the most pathogenic of the three species mentioned above, inhabits the chicken's caeca and may cause hemorrhage that accompanies the emergence of the second stage schizont development (ALLEN, 1997).

According to Allen (1997), during infection the pro-inflammatory cytokines can induce many cells to produce nitric oxide (NO) by induction of NO synthase (iNOS), which shows toxicity to both coccidian parasites and the host cells, and the vasodilatation action is associated with hemorrhage produced during infection.

It is known that the pathogenic effects caused by E. tenella species impair other systems in the chicken's body. A number of studies have evaluated the effects on blood cells. The studies evaluating the hematological parameters in birds infected with Eimeria spp. are generally restricted to the evaluation of the globular volume and some constituents of plasma, such as carotenoids, lipids, and total protein (CONWAY, 1993; ALLEN et al., 1996; 2004; ALLEN, 1997; FETTERER; ALLEN, 2001).

It is important to know the population of blood cells circulating after challenge with coccidiosis in susceptible and immunized birds to better characterize the immunity generated and associated with the pathogenic effects caused by this protozoan.

This study aimed to measure the hematological parameters of two groups, one composed of chickens immunized with E. tenella attenuated strain and another immunized with sporozoite proteins associated with adjuvant and challenged with homologous virulent strain.

\section{Material and Methods}

\section{Experiment place}

The experiment was carried out in the Laboratory of Parasitology and Parasitary Disease (LPPD), Laboratory of Clinical Pathology and Veterinarian Hospital Isolation Sector, pertaining to the Department of Preventive Veterinary Medicine of Universidade Estadual de Londrina (UEL), located in the north of the State of Paraná.

\section{Animals}

Broiler chickens of Hubbard strain, females, coccidian-free, were obtained from a commercial hatchery at the day of hatch and were kept in wire cages with water and food ad libitum. For the multiplication of virulent and attenuated E. tenella strains, 80 birds were provided with feed containing anticoccidial drug until 10 days old; from the $11^{\text {th }}$ day of age onwards the feed was free of anticoccidial drugs. The birds were inoculated on the $15^{\text {th }}$ day, after fasting for 6 hours. In the immunogenicity evaluation, 180 chicks were housed in wire cages and were given manufactured feed in accordance with poultry industry specifications (starter, grower, and finisher), without anticoccidial drugs. All procedures involving animals were conducted in accordance with the principles of Ethical Committee for Experimental Animals of the Universidade Estadual de Londrina (CEEA/UEL), grant number 52/07.

\section{Attenuated strain vaccine, sporozoite protein vaccine, and virulent strain (challenge)}

Used in this study was a virulent strain of Eimeria tenella, obtained in the field after necropsies of infected chickens and maintained in the LPPD through passages in chickens. Attenuation of virulent strain was used according to the technique described by Jeffers (1975), which showed a reduced prepatent period (pp) from 167 hours for the original parent strain to 137 hours over 20 passages (unpublished data). Oocyst purification was collected by salt flotation from their pathological site at the end of the prepatent time according to the procedure described by Long (1971). After excystation and purification of the sporozoite of E. tenella by density gradient centrifugation in Percoll, according to the technique described by Dulski and Turner (1988), proteins of the sporozoite were obtained by sonication, and then were associated with adjuvant Quil A.

\section{Experimental design}

The experiment was designed to include five treatments with three replicates each and 12 birds per replicate, in a completely randomized model. The treatments were: T1 was the unvaccinated, unchallenged control, T2 received 500 attenuated oocysts by gavage and was challenged, T3 was the unvaccinated, challenged control, T4 received $50 \mu \mathrm{g}$ of sporozoite protein + Quil A vaccine by nasal route and was challenged, and T5 received Quil A without sporozoite protein + PBS by nasal route and was challenged. The first day of immunization of the three-day-old chickens was considered as day zero for the purposes of organization and interpretation of the data. The treatments T4 and T5 were boosted by the same route 7 and 21 days after the primary immunization, and treatment $\mathrm{T} 2$ was kept in litter pens after immunization. On the $31^{\text {st }}$ day, the challenge was carried out with sporulated oocysts of homologous virulent strain of the species E. tenella in the dose of $8.0 \times 10^{4}$ oocysts, with the exception of T1.

\section{Blood samples, body weight measurements, and oocyst-counting (OoPG)}

The weighing of food and birds of each replicate were carried out on the challenge day and one week after the challenge to calculate the weight gain (WG) and feed conversion (FC). The lesion score of the treatment (six animals in each treatment) was assessed seven days after either vaccination or challenge, according to the procedure described by Johnson and Reid (1970). The remaining animals were euthanized on day 45 . The oocyst-counting of caecal contents was performed daily for a week in all treatments after the challenge, using the euthanized animals. The hemogram was performed one week after the challenge. Briefly, the blood samples were drawn by cutaneous ulnar vein puncture of three animals of 
each treatment and stored with EDTA. Hematological parameters were evaluated: plasma protein, globular volume, hemoglobin, total erythrocyte and leukocyte count, differential leukocyte count, and determination of erythrocyte indexes (mean corpuscular volume, mean corpuscular hemoglobin concentration, and mean corpuscular hemoglobin), as reported by Campbell (2007). The hemoglobin measurement was determined by the cianometahemoglobin method with a modification: the reagent/blood mixture was centrifuged before the optical density reading to avoid overestimation of hemoglobin concentration. The erythrocyte and leukocyte counts were performed in a 1:200 dilution of blood in Natt and Herrick (1952) solution.

After mixing, the diluted blood was placed on the hemocytometer, remaining at rest for five minutes. The red cells were counted in four large corner squares and in central squares, and the number of cells counted was multiplied by 10,000 to calculate the total number of cells per cubic millimeter. The total leukocyte count was carried out according to the methodology described by Campbell (2007), through the sum of all leukocytes (LEU) present in the nine large squares of the hemocytometer grid area, according to the Equation 1:

$\frac{\mathrm{LEU}}{\mu \mathrm{L}}=($ Total of nine square cells large $+10 \%) \times 200$

The differential counting of leukocytes was performed by preparation of blood smears stained with Giemsa and observed in the $1000 \times$ objective (immersion). Additionally the total plasma protein concentration was determined in a photometric colorimetric test using the Biuret method.

\section{Statistical analysis}

The results were submitted to analysis of variance (ANOVA) and when significant $(\mathrm{p}<0.05)$, the means of variables $\mathrm{WG}$, FC, and hematological parameters were compared by Tukey's test. The student t-test was used to establish differences between the averages of the post-challenge cecal OoPG. The lesion scores (LS) were analyzed by the Kruskal-Wallis non-parametric test and Dunn's multiple comparisons test. A P value of 0.05 was considered significant. Data not normalized were transformed prior to analyses using the Johnson transformation within Minitab. Statistical analyses for all data were performed using Minitab version 14 (Minitab Inc., State College, USA).

\section{Results and Discussion}

\section{Post-challenge clinical and parasitological parameters}

After challenge with virulent homologous strain, the WG and FC showed no statistical significance ( $p>0.05)$, as shown in Table 1 . The lesion score showed significance $(p<0.001)$ in the Kruskal-Wallis test and Dunn multiple comparison test. Two groups were formed: the T3 and T5 treatments (3.75 and 3.33 , respectively) with higher lesion scores; and the T1 and T2 treatments ( 0.00 and 0.17 , respectively) with a minor lesion score. Treatment T4 (1.92) showed intermediate lesion in relation to the two groups above (Table 1).
Table 1. Immunogenicity test carried out seven days after the challenge, with feed conversion, weight gain, and lesion score of treatments

\begin{tabular}{|c|c|c|c|c|}
\hline \multirow[t]{2}{*}{ Treatment } & \multicolumn{3}{|c|}{ Immunogenicity (day 38) } & \multirow{2}{*}{$\frac{\text { Ooc } \times 10^{5} \pm S D}{\text { Day } 38}$} \\
\hline & $\mathrm{FC} \pm \mathrm{SD}$ & WG $(g) \pm S D$ & LS & \\
\hline $\mathrm{T} 1$ & $1.94 \pm 0.08$ & $574 \pm 76$ & $0.00^{b}$ & $0.045 \pm 0.048^{b}$ \\
\hline $\mathrm{T} 2$ & $2.07 \pm 0.06$ & $605 \pm 48$ & $0.17^{\mathrm{b}}$ & $0.017 \pm 0.006^{b}$ \\
\hline $\mathrm{T} 3$ & $1.97 \pm 0.04$ & $535 \pm 19$ & $3.75^{\mathrm{a}}$ & $12.093 \pm 7.268^{\mathrm{a}}$ \\
\hline $\mathrm{T} 4$ & $1.99 \pm 0.17$ & $461 \pm 150$ & $1.92^{\mathrm{ab}}$ & $10.744 \pm 9.987^{\mathrm{a}}$ \\
\hline T5 & $1.98 \pm 0.24$ & $626 \pm 112$ & $3.33^{\mathrm{a}}$ & $13.413 \pm 4.253^{\mathrm{a}}$ \\
\hline P value & 0.753 & 0.314 & 0.00 & 0.005 \\
\hline
\end{tabular}

The indexes $\left(^{(a)}\right.$ and $\left({ }^{b}\right)$ of lesion score and oocyst number, showed the difference of the means determined by nonparametric Kruskal Wallis test followed by Dunn's multiple comparison $(\mathrm{p}<0.05)$ and the difference of means determined by $t$-student test $(\mathrm{p}<0.05)$.

$\mathrm{FC}=$ Feed conversion; $\mathrm{WG}=$ Weight gain; $\mathrm{LS}=$ Lesion score; $\mathrm{SD}=$ Standard deviation; $\mathrm{g}=$ Grams .

Treatments were: $\mathrm{T} 1=$ Negative control; T2 $=$ Received 500 attenuated sporulated oocysts by gavage; T3 = Positive control; T4 = Received $50 \mu \mathrm{g}$ of sporozoite protein + Quil A vaccine; T5 Received Quil A without sporozoite protein + PBS

The number of oocysts per gram of cecal contents was significantly decreased $(\mathrm{p}<0.01)$ in the T1 and T2 treatments in comparison to X group, while the T3, T4, and T5 treatments showed high oocyst counts.

The challenge with $8 \times 10^{4}$ oocysts per bird was not enough to cause significant differences between the WG and FC parameters. To induce clinical or subclinical coccidiosis to evaluate hematological data it might be necessary to give a higher challenge dose. However, the parasitological parameters showed a pathogenic effect in the positive control treatment, caused by the challenge and shown by their high lesion scores and the highest oocyst production, which we believe were sufficient for the hematological evaluation. Briefly, we evaluated the bird hematological changes with a challenge capable of causing the clinical coccidiasis form.

\section{Hematological parameters post-challenge}

The analysis of variance showed no significant differences ( $p>0.05$ ) among treatments for plasma protein, globular volume $(\mathrm{GV})$, hemoglobin (HB), total erythrocytes (TE), leukocytes (LEU), lymphocytes (LYMPH), heterophils (HET), eosinophils (EOS), monocytes $(\mathrm{MON})$, and erythrocyte indexes (mean corpuscular hemoglobin, mean corpuscular hemoglobin concentration, and mean corpuscular volume), as shown at Tables 2 and 3.

Only little information is available in the literature concerning the evaluation of hematologic alterations in birds infected with E. tenella. The few studies which have analyzed hematological parameters are restricted to the leukocyte profile and type of immune response to infection caused by the parasite.

Conway et al. (1993) assessed levels of infection by E. tenella and other species and observed a gradual decrease of the globular volume, plasma total protein, weight gain, and increased feed conversion to the number of inoculated oocysts. These results were not reproduced in this experiment because of the challenge 
Table 2. Haematological means values \pm standard deviation of plasma protein (PP), globular volume (GV), hemoglobin (HB), total erythrocytes (TE), mean corpuscular volume (MCV), mean corpuscular hemoglobin concentration (MCHC), and hemoglobin corpuscular media (HCM)

\begin{tabular}{|c|c|c|c|c|c|c|c|}
\hline Treatment & PP (g.dL $\left.{ }^{-1}\right)$ & GV (\%) & HB (g.dL $\left.{ }^{-1}\right)$ & $\mathrm{TE}\left(\times 10^{6} \cdot \mathrm{mL}^{-1}\right)$ & HCM (pg) & $\operatorname{MCV}(f)$ & $\mathrm{CHCM}\left(\mathrm{g} \cdot \mathrm{dL}^{-1}\right)$ \\
\hline $\mathrm{T} 1$ & $4.2 \pm 0.4$ & $30 \pm 3.0$ & $8.97 \pm 0.67$ & $2.31 \pm 0.68$ & $40.8 \pm 10.1$ & $136.3 \pm 34.1$ & $30.0 \pm 1.3$ \\
\hline $\mathrm{T} 2$ & $4.3 \pm 0.2$ & $30 \pm 1.0$ & $8.03 \pm 0.90$ & $1.89 \pm 0.27$ & $43.4 \pm 10.0$ & $161.4 \pm 29.1$ & $26.8 \pm 3.2$ \\
\hline T3 & $4.2 \pm 0.1$ & $30 \pm 2.7$ & $8.97 \pm 0.65$ & $2.12 \pm 0.35$ & $43.4 \pm 9.8$ & $146.2 \pm 36.0$ & $29.8 \pm 0.6$ \\
\hline T4 & $4.0 \pm 0.5$ & $31 \pm 4.9$ & $8.15 \pm 0.64$ & $3.02 \pm 1.79$ & $32 \pm 16.9$ & $116.9 \pm 52.9$ & $16.9 \pm 2.3$ \\
\hline T5 & $4.0 \pm 0.1$ & $30 \pm 5.7$ & $8.70 \pm 1.27$ & $2.42 \pm 0.06$ & $36.1 \pm 6.2$ & $124.6 \pm 16.7$ & $29.1 \pm 1.2$ \\
\hline P value & 0.64 & 0.99 & 0.55 & 0.60 & 0.74 & 0.67 & 0.21 \\
\hline
\end{tabular}

The data set was analyzed by ANOVA and when statistically significant $(\mathrm{p}<0.05)$, the mean of the treatments were compared by Tukey's test.

Table 3. Haematological mean values \pm standard deviation of leukocytes, the absolute and relative values of lymphocytes, heterophils, monocytes, and eosinophils

\begin{tabular}{|c|c|c|c|c|c|c|c|c|c|}
\hline \multirow[t]{2}{*}{ Treatment } & \multirow{2}{*}{$\begin{array}{l}\text { Leukocytes } \\
\left(\times 10^{3} \cdot \mu \mathrm{L}^{-1}\right)\end{array}$} & \multicolumn{2}{|c|}{ Lymphocytes } & \multicolumn{2}{|c|}{ Heterophils } & \multicolumn{2}{|c|}{ Monocytes } & \multicolumn{2}{|c|}{ Eosinophils } \\
\hline & & $\left(\times 10^{3} \cdot \mu \mathrm{L}^{-1}\right)$ & $(\%)$ & $\left(\times 10^{3} \cdot \mu \mathrm{L}^{-1}\right)$ & $(\%)$ & $\left(\times 10^{3} \cdot \mu \mathrm{L}^{-1}\right)$ & $(\%)$ & $\left(\times 10^{3} \cdot \mu \mathrm{L}^{-1}\right)$ & $(\%)$ \\
\hline $\mathrm{T} 1$ & $12.5 \pm 0.6$ & $7.8 \pm 1.9$ & $62.3 \pm 14.5$ & $4.0 \pm 2.1$ & $32.3 \pm 16.5$ & $0.0 \pm 0.0$ & $0.0 \pm 0.0$ & $0.7 \pm 0.5$ & $5.3 \pm 3.8$ \\
\hline $\mathrm{T} 2$ & $14.1 \pm 3.6$ & $7.9 \pm 1.9$ & $56.3 \pm 4.2$ & $5.3 \pm 2.2$ & $36.7 \pm 6.5$ & $0.2 \pm 0.2$ & $1.0 \pm 1.0$ & $0.7 \pm 0.6$ & $6.0 \pm 5.2$ \\
\hline T3 & $15.5 \pm 7.7$ & $9.6 \pm 5.9$ & $58.3 \pm 10.6$ & $4.5 \pm 1.2$ & $33.0 \pm 10.8$ & $1.0 \pm 0.5$ & $6.0 \pm 1.0$ & $0.4 \pm 0.2$ & $2.7 \pm 5.8$ \\
\hline $\mathrm{T} 4$ & $14.1 \pm 4.7$ & $8.7 \pm 4.9$ & $59.0 \pm 15.6$ & $3.9 \pm 1.9$ & $32.0 \pm 24.0$ & $1.0 \pm 1.5$ & $6.0 \pm 8.5$ & $0.4 \pm 0.1$ & $3.0 \pm 0.0$ \\
\hline T5 & $15.6 \pm 5.6$ & $8.5 \pm 1.8$ & $56.0 \pm 8.5$ & $5.5 \pm 4.4$ & $32.5 \pm 16.3$ & $0.8 \pm 1.1$ & $6.5 \pm 9.2$ & $0.8 \pm 0.5$ & $5.0 \pm 1.4$ \\
\hline P value & 0.94 & 0.98 & 0.96 & 0.92 & 0.99 & 0.35 & 0.37 & 0.78 & 0.70 \\
\hline
\end{tabular}

The data set was analyzed by ANOVA and when statistically significant $(\mathrm{p}<0.05)$, the mean of the treatments were compared by Tukey's test.

not being able to cause clinical or sub-clinical disease and due to the time of blood sampling after the challenge.

Changes in peripheral blood leukocytes from chickens affected by $E$. tenella were detected only in primary infections in a study conducted by Natt (1959), where severe bleeding was detected.

Rose et al. (1979) observed that first infection with E. maxima in the chicken leads to an increase in the circulating leukocytes number (heterophils, lymphocytes, and monocytes) in two phases, one lymphocytosis before and another after the peak production of oocysts. In the period when the oocyst production reached a peak, infected birds had lymphopenia, so that the number of circulating leukocytes did not differ statistically from the control group. Challenge with homologous strain in the immunized birds showed a rapid and short immune response, returning to normal levels on the second day post-challenge.

In assessing the leukocyte response of immunized and challenged birds, Rose et al. (1984) observed a significant decrease in the peripheral leukocytes number one hour after oocyst inoculation, due to circulating lymphocytes depletion. Then there was a gradual increase of the leukocytes, and after seven hours the cells of the immunized group were above the total count of the control group. The leukocytosis was later found to be related to the increased number of circulating heterophils. These facts could explain the absence of leukocyte changes in this study. According to the authors above, changes in the cell number do not occur during the peak production of oocysts. Another possibility would be that the challenge was not pathogenic enough to cause cellular changes, due to non-significance of the weight gain and feed conversion parameters.

The number of eosinophils in this study was similar between infected and control animals, in agreement with the study by Rose et al. (1979) with E. maxima species. Unlike in mammals, the role of eosinophil in birds is not fully known and studies have shown its participation in reactions of type IV hypersensitivity (delayed), as occurs with mammalian eosinophils (CAMPBELL, 2007).

\section{Correlations between evaluated parameters}

Significant correlations $(\mathrm{p}<0.05)$ were detected between WG and TE $(\mathrm{r}=-0.74) ; \mathrm{MON}$ and $\mathrm{FC}(\mathrm{r}=0.57)$; lesion scores and the OPG $(r=0.69)$; lesion score and TE $(r=0.56)$; and lesion score and MON $(r=0.76)$. There were significant correlations between the hematological parameters: GV and HB $(r=0.65)$; GV and plasma protein $(\mathrm{r}=0.63)$; GV and HET $(\mathrm{r}=-0.57)$; GV and MON ( $r=0.60)$; HB and plasma protein $(r=0.60)$; LYMPH and HET $(r=-0.94)$; and HET and MON $(r=-0.55)$. The correlations of all parameters used in this immunogenicity study are listed in Table 4. Based on these results, some hypotheses on the pathogenesis of the disease have been proposed to explain the interactions between the parameters under the conditions in which the experiment was carried out.

The hematological parameters TE, GV, and HB are generally associated with hydration levels and/or hemorrhage. The correlation between the WG $\times$ TE $(r=-0.74$ and $p=0.004)$ is inversely proportional, suggesting that if a decrease in weight gain occurs, it may be accompanied by an erythrocyte concentration in challenged birds. The other correlations are as follows: $\mathrm{TE} \times$ lesion score $(\mathrm{r}=0.558$ and $\mathrm{p}=0.048) ; \mathrm{HB} \times$ plasma protein $(\mathrm{r}=0.604$ and $\mathrm{p}=0.029) ; \mathrm{GV} \times$ plasma protein $(\mathrm{r}=0.630$ and $\mathrm{p}=0.021)$; and $\mathrm{HB} \times \mathrm{GV}(\mathrm{r}=0.651$ and $\mathrm{p}=0.016)$ indicate $\mathrm{a}$ direct relationship between the variables. All correlations above are linked to dehydration due to diarrhea, increased intestinal 
transit, decreased water absorption in the caecum, and plasma exudation caused directly by the interaction between the parasite and the affected organ (WILLIAMS, 2005).

These results are in agreement with those obtained by Fukata et al. (1997), who obtained a reduction in levels of plasma proteins $(\mathrm{p}<0.01)$ on the fourth day post-infection by E. tenella. On the seventh day post-infection, the number of red blood cells and globular volume also showed a decrease compared to the negative control $(\mathrm{p}<0.001)$.

There was a strong inverse correlation between the LYMPH and HET in the plasma $(r=-0.958$ and $\mathrm{p}<0.001)$, indicating that the prevalence of these cells changes according to the degree of bird susceptibility. The same was observed with the MON and HET number, but at lower intensity $(r=-0.564$ and $\mathrm{p}=0.044)$. The prevalence of these cells in the cecal tissue of the different treatments was not assessed. Briefly, these correlations suggest a partial replacement between lymphocytes and heterophils in the development of immune response against Eimeria tenella.

The correlation between the lesion scores and OPG $(r=0.689$ and $\mathrm{p}=0.004)$ indicates indirectly that a larger amount of parasites in the ceacum causes a higher lesion score. Rose et al. (1979) suggested that a greater proliferation of monocytes may be highly associated with removal of the considerable amount of debris and may serve to assist in the defense against parasites in the affected tissue.
Based on the information above, we found an increased number of monocytes when the lesion was more severe, as is shown in the result of lesion score $\times \operatorname{MON}(r=0.764$ and $p=0.002)$. In the Rose et al. (1979) study, an increase of the monocyte number was more pronounced at the end of the cycle of the parasite, after the peak production of oocysts.

The correlation between FC and MON ( $r=0.569$ and $\mathrm{p}=0.042$ ) suggests that an increase in feed conversion is associated with large amounts of monocytes. The set of factors that reflect in the bird performance is complex, involving many variables in host-parasite relationship. Johnson (1997) cites that the proinflammatory cytokines, produced by several cell types, among which are the monocytes, are responsible for low growth in immunologically challenged animals. Although this result appears to give evidence of a pathogenic effect associated with this type of cell, under conditions in which this experiment was conducted, we do not have enough support to sustain this assertion.

The assessment of groups with different susceptibility levels to a single challenge facing the correlations showed GV $\times$ HET $(\mathrm{r}=-0.574$ and $\mathrm{p}=0.04)$ and $\mathrm{GV} \times \operatorname{MON}(\mathrm{r}=0.600$ and $\mathrm{p}=0.030$ ), suggesting that levels of hydration and hemorrhage caused by the challenge suffer changes according to the predominance of heterophils or monocytes. Conway et al. (1993) observed that the greater the challenge of susceptible birds, the lower the globular volume.

Table 4. Correlation coefficient ( $\mathrm{r}$ ) and P values between the parameters used to evaluate the immunity in birds after challenge with homologous virulent strain of E. tenella on the $38^{\text {th }}$ day

\begin{tabular}{|c|c|c|c|c|c|c|c|c|c|c|c|c|c|}
\hline \multirow{2}{*}{\multicolumn{2}{|c|}{ Parameter }} & \multicolumn{12}{|c|}{ Parameter } \\
\hline & & WG & FC & LS & OPG & GV & HB & TE & LEU & PP & HET & EOS & LYMP \\
\hline \multirow{2}{*}{ FC } & $\mathrm{r}$ & -0.053 & & & & & & & & & & & \\
\hline & $\mathrm{P}$ & 0.863 & & & & & & & & & & & \\
\hline \multirow{2}{*}{ LS } & $\mathrm{r}$ & -0.303 & 0.124 & & & & & & & & & & \\
\hline & $\mathrm{P}$ & 0.314 & 0.686 & & & & & & & & & & \\
\hline \multirow{2}{*}{ OPG } & $\mathrm{r}$ & -0.179 & -0.209 & 0.689 & & & & & & & & & \\
\hline & $\mathrm{P}$ & 0.558 & 0.492 & 0.004 & & & & & & & & & \\
\hline \multirow{2}{*}{$\mathrm{HT}$} & $\mathrm{r}$ & 0.048 & 0.536 & 0.222 & 0.057 & & & & & & & & \\
\hline & $\mathrm{P}$ & 0.876 & 0.059 & 0.466 & 0.853 & & & & & & & & \\
\hline \multirow{2}{*}{$\mathrm{HB}$} & $\mathrm{r}$ & 0.062 & 0.265 & 0.292 & 0.042 & 0.651 & & & & & & & \\
\hline & $\mathrm{P}$ & 0.841 & 0.381 & 0.333 & 0.893 & 0.016 & & & & & & & \\
\hline \multirow{2}{*}{$\mathrm{TE}$} & $\mathrm{r}$ & -0.742 & 0.353 & 0.558 & 0.247 & 0.115 & 0.244 & & & & & & \\
\hline & $\mathrm{P}$ & 0.004 & 0.237 & 0.048 & 0.415 & 0.708 & 0.423 & & & & & & \\
\hline \multirow{2}{*}{ LEU } & $\mathrm{r}$ & -0.281 & -0.004 & 0.366 & 0.131 & -0.34 & -0.485 & 0.187 & & & & & \\
\hline & $\mathrm{P}$ & 0.353 & 0.989 & 0.219 & 0.670 & 0.255 & 0.093 & 0.540 & & & & & \\
\hline \multirow{2}{*}{$\mathrm{PP}$} & $\mathrm{r}$ & -0.098 & 0.490 & 0.042 & -0.395 & 0.63 & 0.604 & 0.118 & -0.075 & & & & \\
\hline & $\mathrm{P}$ & 0.749 & 0.089 & 0.892 & 0.181 & 0.021 & 0.029 & 0.700 & 0.808 & & & & \\
\hline \multirow{2}{*}{ HET } & $\mathrm{r}$ & 0.066 & -0.427 & -0.314 & -0.154 & -0.574 & -0.392 & -0.146 & -0.236 & -0.372 & & & \\
\hline & $\mathrm{P}$ & 0.829 & 0.146 & 0.296 & 0.615 & 0.040 & 0.186 & 0.634 & 0.437 & 0.211 & & & \\
\hline \multirow{2}{*}{ EOS } & $\mathrm{r}$ & 0.149 & -0.020 & -0.288 & -0.115 & -0.107 & 0.111 & -0.163 & -0.326 & 0.014 & -0.194 & & \\
\hline & $\mathrm{P}$ & 0.626 & 0.948 & 0.340 & 0.708 & 0.729 & 0.718 & 0.595 & 0.278 & 0.964 & 0.525 & & \\
\hline \multirow{2}{*}{ LYMPH } & $\mathrm{r}$ & -0.035 & 0.270 & 0.113 & -0.036 & 0.470 & 0.282 & -0.030 & 0.322 & 0.399 & -0.938 & 0.105 & \\
\hline & $\mathrm{P}$ & 0.908 & 0.373 & 0.713 & 0.908 & 0.105 & 0.350 & 0.922 & 0.283 & 0.176 & 0.000 & 0.733 & \\
\hline \multirow{2}{*}{ MON } & $\mathrm{r}$ & -0.195 & 0.569 & 0.764 & 0.541 & 0.600 & 0.369 & 0.539 & 0.170 & 0.146 & -0.564 & -0.354 & 0.338 \\
\hline & $\mathrm{P}$ & 0.523 & 0.042 & 0.002 & 0.056 & 0.030 & 0.215 & 0.057 & 0.578 & 0.634 & 0.044 & 0.236 & 0.259 \\
\hline
\end{tabular}

$\mathrm{WG}=$ Weight gain; FC = Feed conversion; LS = Lesion score; OPG = Number of oocysts per gram of cecal contents; GV = Globular volume; HB = Hemoglobin; $\mathrm{TE}=$ Total erythrocyte; LEU = Leukocyte; PP = Plasma protein; HET = Heterophils; EOS = Eosinophils; LYMPH = Lymphocytes; MON = Monocytes. 
Under the conditions in which the experiment was carried out, we can conclude that the treatments did not differ by ANOVA, possibly because the challenge was not as pathogenic as expected. The failure to verify changes in erythrocyte and especially the peripheral leukocyte count of chickens challenged with $E$. tenella virulent strains may be influenced by the period during which blood was collected, which corresponded to the peak of oocyst production.

The correlations suggest that the presence of circulating monocytes has a direct relation with the lesion score increase, feed conversion, and number of oocyst shedding. Due to the higher number of parasites in the lesion site, there is demand for a greater quantity of phagocytes. The correlations of blood parameters GV, $\mathrm{TE}, \mathrm{HB}$, and plasma proteins with other parameters, such as WG, OPG, and lesion score showed levels of hemorrhage and/or hydration, as a consequence of effects of the parasite aggression to the tissue.

\section{References}

ALLEN, P. C. et al. Association of lowered carotenoids with protection against cecal coccidiosis by diets high in n-3 fatty acids. Poultry Science, v. 75, n. 8, p. 966-972, 1996.

ALLEN, P. C. Nitric oxide production during Eimeria tenella infections in chickens. Poultry Science, v. 76, n. 6, p. 810-813, 1997.

ALLEN, P. C.; DANFORTH, H. D.; VINYARD, B. L. Development of a protective index to rank effectiveness of multiple treatments within an experiment: application to a cross-protection study of several strains of Eimeria maxima and a live vaccine. Avian Disease, v. 48, n. 2, p. 370-373, 2004.

CAMPBELL, T. W. Hematologia de mamíferos não domésticos, aves, répteis, peixes e anfíbios comuns. In: THRALL, M. A. Hematologia e Bioquímica Clínica Veterinária. 1 ed. São Paulo: Editora Roca, 2007. p. 215-247.

CONWAY, D. P. et al. Effects of different levels of oocyst inocula of Eimeria acervulina, E. tenella, and E. maxima on plasma constituents, packed cell volume, lesion scores, and performance in chickens. Avian Disease, v. 31, n. 7, p. 118-123, 1993.

DULSKI, P.; TURNER, M. The purification of sporocysts and sporozoites from Eimeria tenella oocysts using percoll density gradients. Avian Disease, v. 32, n. 2, p. 235-239, 1988.
FETTERER, R. H.; ALLEN, P. C. Eimeria tenella infection in chickens: effect on plasma and muscle 3-methylhistidine. Poultry Science, v. 80, n. 11, p. 1549-1553, 2001.

FUKATA, T. et al. Evaluation of plasma chemistry and haematological studies on chickens infected with Eimeria tenella and E. acervulina. Veterinary Record, v. 141, n. 2, p. 44-46, 1997.

JEFFERS, T. K. Attenuation of Eimeria tenella through selection for precociousness. Journal of Parasitology, v. 61, n. 6, p. 1083-1090, 1975.

JOHNSON, J.; REID, W. M. Anticcocidial drugs: lesion scoring techniques in battery and floor-pen experiments with chickens. Experimental Parasitology, v. 28, n. 1, p. 30-36, 1970.

JOHNSON, R. W. Inhibition of growth by pro-inflammatory cytokines: an integrated view. Journal of Animal Science, v. 75, n. 5, p. 1244-1255, 1997.

LILLEHOJ, H. S.; MIN, W.; DALLOUL, R. A. Recent progress on the cytokine regulation of intestinal immune responses to Eimeria. Poultry Science, v. 83, n. 4, p. 611-623, 2004.

LONG, P. L. Maintenance of intestinal protozoa in vivo with particular reference to Eimeria and Histomonas. In: TAYLOR, A. E. R.; MULLER, R. Isolation and Maintenance of Parasites In Vivo. Oxford: Blackwell Scientific Publication, 1971. p. 65-75.

NATT, M. P. The effect of cecal coccidiosis on the blood cells of the domestic fowl. 3. The changes in the leucocyte picture during the course of the infection. Experimental Parasitology, v. 8, n. 2, p. 182-187, 1959.

NATT, M. P.; HERRICK, C. A. A new blood diluent for counting the erythrocytes and leucocytes of the chicken. Poultry Science, v. 31, n. 1, p. 735-738, 1952.

ROSE, M. E.; HESKETH, P.; OGILVIE, B. M. Peripheral blood leucocyte response to coccidial infection: a comparison of the response in rats and chickens and its correlation with resistance to reinfection. Immunology, v. 36, n. 1, p. 71-79, 1979.

ROSE, M. E.; HESKETH, P.; RENNIE, M. Coccidiosis: rapid depletion of circulating lymphocytes after challenge of immune chickens with parasite antigens. Infection and immunity, v. 45, n. 1, p. 166-171, 1984.

WILLIAMS, R. B. Intercurrent coccidiosis and necrotic enteritis of chickens: rational, integrated disease management by maintenance of gut integrity. Avian Pathology, v. 34, n. 3, p. 159-180, 2005. 